\section{The Elaboration Process of the Sustainability Report: A case study}

\author{
Darliane Ribeiro Cunha ${ }^{1}$ \\ ${ }^{1}$ Federal University of Maranhão, Department of Accounting \\ and Management, São Luis, Brazil \\ José Mariano Moneva ${ }^{2}$ \\ ${ }^{2}$ University of Zaragoza, Department of Accounting \\ and Finance, Zaragoza, Spain
}

Received on

07/31/2017

Approved on

$02 / 28 / 2018$

Responsible editor:

Profa. Dra . Leire San-Jose

Evaluation process:

Double Blind Review

\begin{abstract}
Purpose - The paper aims to use legitimacy theory to identify the main drivers that influence the elaboration and publication of sustainability reports of companies belonging to environmentally sensitive sectors.

Design/methodology/approach - A case study was developed through structured interviews with the managers of sustainability departments or equivalent, all of them belonging to chemical and oil companies in Brazil and Spain.

Findings - The results show that the companies surveyed in the study consider the sustainability report to be an instrument of accountability to their stakeholders. Transparency and legitimacy of their activities stand out among the main reasons that influence its publication.

Originality/value - The interest in offering a significant contribution that inspires, promotes, and encourages Corporate Social Responsibility by companies is one of the motives for conducting studies in this area. Sectors with a high environmental impact call the attention to a multiplicity and variety of interest groups. For this reason, it is of interest to conduct studies aimed at these sectors.
\end{abstract}

Keywords - Corporate Social Responsibility; Sustainability Report; Stakeholders; Theory of Legitimacy.

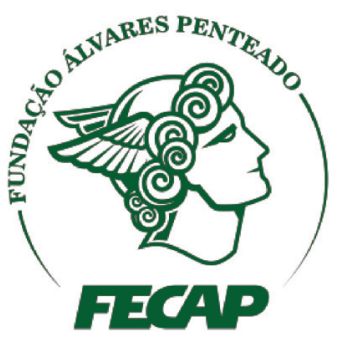

Review of Business Management

DOI: $10.7819 /$ rbgn.v0i0.3948 


\section{Introduction}

Today, many interest groups demand social and environmental aspects to be considered as key variables in understanding the performance and strategic position of companies. Until recently, the concern with these aspects in business activities had involved a small group of companies. Today, however, the significant growth in the number of companies that have begun to adopt the concept of Corporate Social Responsibility (CSR) is evident and noticeable, especially among large organizations and business groups (Moneva, 2005b). As an example, in 2015, $92 \%$ of the 250 largest Fortune 500 companies in the world elaborated their reports following the principles of CSR, while in 2005 and 2008, that percentage barely reached $64 \%$ and $83 \%$, respectively (KPMG, 2015).

CSR disclosure practices are increasingly being used by large companies as instruments to eliminate the information asymmetries of stakeholders (Navarro, Alcaraz, \& Ortiz, 2010). Previous studies highlight the constant increase in this type of information (Alazzani \& Wan-Hussin, 2013; Bonsón \& Bednárová, 2015; Husillos, 2007; Larrinaga, Carrasco, Correa, Llena, \& Moneva, 2002; Moseñe, Burritt, Sanagustin, Moneva, \& Tingey-Holyoak, 2013).

Companies need to disclose their CSR actions to improve their reputations, but they must do it correctly, with transparency and in a reliable, understandable, and timely manner (Baraibar-Diez \& Sotorrío, 2018).

In the literature it is observed that one motivation to increase the dissemination of CSR information consists of the attempt by companies to achieve legitimacy in the eyes of society and institutions (Husillos, 2007). Organizations try to make sure that they act, or at least appear to act, within the limits of the rules established for the societies in which they operate (Deegan, Rankin, \& Tobin, 2002).

The obligation to achieve legitimacy is a constant in the business context, together with the growing demand for social and environmental information from different stakeholders. The theory of legitimacy can explain the relationships between the company and society. According to this approach, there is a contract between a company and society in which society requires the services of the company, which, in turn, receives the approval of society. This contract, which involves meeting the expectations of both parties, is dynamic in character and can be modified or revoked when one of them does not meet the expectations of the other (Archel, 2003).

Legitimacy requires companies to modify their actions so that they are acceptable to the community and to make it known that such actions are consistent with social values (Frost $\&$ Seamer, 2002).

Husillos (2007) observes that the publication of information on CSR initially serves to respond to the demands and pressure from interest groups and, consequently, the desire of the entity to achieve legitimacy in the eyes of its main stakeholders. Therefore, it is of interest to identify and know the elements that exert a greater or lesser influence on the decision of business managers to disseminate information on CSR, for this could allow the identification of a disclosure profile, as well as add an important contribution to the knowledge on the tendencies of organizations in this respect, serving as a reference and incentive to achieve greater disclosure of environmental information, in accordance with social values, norms, and conventions.

The theory of legitimacy involves users being offered positive information about the social and environmental performance of a company in order to form a positive image of it and with the intention of achieving maximum acceptance by the stakeholders related to it (Gray, Owen, \& Adams, 1996).

To achieve legitimization it is very important for companies to take into account the quality and relevance of the reported CSR information (Iatridis, 2013). The previous literature that has analyzed the content of 
sustainability reports reveals limited and partial disclosure of this type of information (Alazzani \& Wan-Hussin, 2013; Bonsón \& Bednárová, 2015; Moseñe et al., 2013).

The interest of companies in making their commitment to the environment visible, so as to achieve legitimacy, leads them to consider sustainability as a key variable in their management. The sustainable management of companies must take into consideration not only a series of policies aimed at complying with the three aspects of the Triple Bottom Line, but companies must also incorporate various stakeholders into their activities, offering them appropriate, timely, and complete accountability (Moneva, 2005a).

Thus, companies have to determine which interest groups they must not only provide information to but also make part of the accountability process. In this context, this investigation is developed in order to answer the following question: "What reasons can influence the development and publication of companies' sustainability reports?” Based on this question, the paper aims to identify the factors that influence the elaboration and publication of the sustainability reports of four companies (three Brazilian and one Spanish) belonging to environmentally sensitive sectors (oil, chemicals, and energy).

\section{Literature review}

In the academic literature, several papers are found that use the case method to explore the main factors that could be influencing the elaboration, development, and dissemination of sustainability reports. In the European context, the studies by Albelda, Correa, and Carrasco (2007), Husillos, Larrinaga, and Álvarez (2011), Llena (1999), and O`Dwyer (2002) are relevant.

Llena (1999) conducted an investigation based on interviews with 6 companies in the chemical and oil sectors. In this study, the author highlights the need to establish criteria for accounting performance, both external and internal. It also mentions that standards for the treatment and presentation of financial and nonfinancial information of an environmental nature must be established.

In his study, Llena (1999) highlights that as the main reasons for their environmental performance, the companies analyzed consider those generated internally, either through their own commitment or through imposition by their parent corporations; while of all the external pressures received, the legal one is the most influential in their behavior.

O`Dwyer (2002) conducted a study of 27 Irish companies to investigate the factors that influence environmental disclosure. The results indicate that managers do not use sustainability information as a mechanism to achieve legitimacy. Albelda et al. (2007) investigated environmental management and accounting practices in 10 Spanish companies. The study identified factors that can influence environmental performance, such as: employee awareness, knowledge of the environment, the skills and experience of employees, the commitment of managers, the coordination of cross-functionalities, the integration of environmental issues into the strategic planning process, and the use of management accounting practices.

Husillos et al. (2011) conducted a study with the objective of exploring the main factors that could be influencing the elaboration and development of sustainability reports in the Spanish context. For this study, 30 semistructured interviews were carried out with managers involved in the elaboration of the sustainability reports of 20 Spanish companies. The results of the paper suggest that both the internal context (organizational and individual) and the external one influence the decision to elaborate a sustainability report and the process of doing so.

The influence of stakeholders in the elaboration and presentation of sustainability reports is evident and essential. In the study by Deegan and Blomquist (2006) of Australian 
stakeholders, it was possible to note this attitude. The results of the study show that companies are willing to listen to an NGO and make changes or modify their behavior.

\section{Methodology}

\section{I Classification of the investigation}

This study is based on a qualitative analysis, using the case study method, which is a qualitative and empirical research method geared towards obtaining an in-depth understanding of an object, event, process, or event in its natural context. Yin (2009) notes that an empirical investigation studies a contemporary phenomenon in its real context, when the borders between the phenomenon and the context are evident and in which multiple sources of evidence are used.

According to Hernández (2012), this type of research, unlike an external observation approach to the object of study, allows researchers to "approach" the participants of the companies under study, to access their internal logic and interpret the subjective understanding of their reality.

One of the main biases associated with case studies is that their conclusions are not statistically generalizable, since they do not represent a sample of a specific population or universe. However, they can help to develop theoretical propositions, since the objective of the researcher is to broaden and generalize theories - analytical generalization - and not to enumerate frequencies - statistical generalization (Yin, 2009).

Yin (2009) considers the case study method to be appropriate for those topics that are considered novel or that require further analysis of behavior, because, in his opinion, empirical research has the following distinctive features: it examines or investigates a contemporary phenomenon in its real environment; the boundaries between the phenomenon and its context are not clearly evident; multiple sources of data can be used, and both a single case and multiple cases can be studied.
Thus, this study uses the multiple case study method, examining 4 companies, three Brazilian and one Spanish. The companies are called A, B, C, and D without following a constant order. The application of the case study method consists of carrying out structured interviews with the managers of the sustainability area or their equivalent. The interview with the managers included a total of 19 open and closed questions, of which 17 addressed the topic of sustainability and 2 were to outline the profile of the person being interviewed.

Using the case study method, research can be carried out in a more internal and deeper context than with the other methods. The interview guide was prepared based on a review of the literature on accounting, environment, and sustainability using the case study method (Husillos et al., 2011; Llena, 1999; O’Dwyer, 2002).

The interview addresses the following aspects: means used by companies to publish sustainability information; reasons for the publication of sustainability information; stakeholders and publication of sustainability information; participation of companies in the sustainable investment stock index and in associations or initiatives and the reasons for their participation; elaboration and publication of sustainability reports; and external verification of the sustainability report.

The analysis was carried out in 2012, during the period from July to October. Initially, a letter was sent with the invitation to participate in the study, indicating the corresponding link to the interview hosted on the Survey Monkey platform. When necessary, interviews were completed through telephone calls or email messages with the person. We also obtained data on the companies from their web pages.

\subsection{Companies analyzed}

The selection of the companies for the study identified ones that are considered references in their respective sectors in Brazil 
and Spain, namely: Deten Química SA (Deten), Petróleo Brasileiro SA (Petrobras), Repsol SA (Repsol), and Grupo Votorantim (Votorantim). Prior to the results analysis, a review of each of the companies is presented.

Deten is a Brazilian company controlled by CEPSA Química (72\% share), which is a corporation of Spanish origin and which has operated in the chemicals sector since it started its activities in 1981.

The company makes the sustainability reports for the period 2010-2013 available on its website under the title Social Balance. It does not use the GRI guidelines for the elaboration of its sustainability reports.

Petrobras is a Brazilian company of mixed capital (public and private) with majority public ownership. It started operations in 1953 and is currently present in 18 countries, with a total of 80,908 employees. The activities developed by the company include the generation of electric power, petrochemicals, the exploration and production of oil and gas, refining oil and gas, distribution, the production of biofuels, and the transportation and marketing of biofuels. According to the PFC Energy 50 ranking of 2014, Petrobras is the 9th largest energy company in the world, after ExxonMobil, Chevron, Royal Dutch Shell, Petrochina, BP, Total, Schlumberger, and Gazprom. The PFC Energy 50 ranking presents a ranking of energy companies based on their market value.

Petrobras makes sustainability reports for the period 2005-2014 available on its website. The sustainability report for the period 20052008 was called the Social and Environmental Balance. In 2014, the non-financial and GRI data was externally verified by the firm PricewaterhouseCoopers.

In 1927, the Repsol group was created (its former name being CAMPSA), and it currently operates in more than 40 countries and has more than 27,000 employees. Its activities are related to the exploration and production, refining, and marketing of oil and natural gas and new energies. According to the PFC Energy 50 ranking of 2014, Repsol is the 45th largest energy company in the world.

Since 2005, Repsol has presented its sustainability report on its website under the title Corporate Responsibility Report. In 2014, the non-financial and GRI data was externally verified by the firm Deloitte and, according to the GRI database, Repsol have had an A + investment grade since 2006.

For the elaboration of the 2014 Corporate Responsibility Report, Repsol considered a representative group of interested parties. In the report, the company highlights:

"the participation of the main trade union organizations of the company in Spain, in the elaboration of this Report, through the Corporate Social Responsibility (CSR) working group constituted by representatives of the trade union organizations Comisiones Obreras (CC.OO.) and General Union of Workers (UGT), and people from the Labor Relations and Corporate Responsibility units of Repsol. "

Votorantim Group is a Brazilian company, with private-only capital, that started its activities in 1918. The company operates in business segments such as energy, cement, steel, metals, and others. Currently, it operates in 19 countries and is present in the continents of America, Africa, Asia, Europe, and Oceania. It has 44,322 employees (76\% in Brazil).

Table 1 shows the reports available on the web pages of the companies analyzed in the study. It is possible to observe a wide availability of reports. Votorantim stands out for having published integrated reports since 2011 . 
Table 1

Information available on the website

\begin{tabular}{|c|c|c|c|c|}
\hline & Sustainability Report & Annual report & Integrated report & $\begin{array}{c}\text { External verification of the } \\
\text { sustainability report }\end{array}$ \\
\hline Deten & $2010-2014$ & $2010-2014$ & - & Does not inform \\
\hline Petrobras & $2005-2014$ & 2006-2014 & - & $2005-2014$ \\
\hline Repsol & $2005-2014$ & $2008-2014$ & - & $2005-2014$ \\
\hline Votorantim & 2010 & $2007-2010$ & 2011-2014 & 2010-2014 \\
\hline
\end{tabular}

Source: Deten http://www.deten.com.br/; Petrobras http://www.petrobras.com.br/; Repsol https://www.repsol.es; Votorantim http://www.votorantim.com.br/

\section{Results}

To achieve a better and clearer presentation of the information obtained from the application of the interviews in the companies Deten, Petrobras, Repsol, and Votorantim, the results are classified into three sections: (a) sustainability information, motivations for publication, and interest groups; (b) indexes and initiatives related to sustainability; and (c) elaboration and publication of sustainability reports.

\section{I Sustainability information, motivations for publication, and interest groups}

All the companies analyzed disclose their sustainability information through a specific report on this subject. However, one of them publishes this information in an integrated report; that is, it does so in conjunction with the annual report.

In general, it is noted that the companies emphasize the importance of considering multiple users of information. For instance, company A “(...) annually produces a social and environmental report, available on our website, in order to disseminate the results to stakeholders".

Similarly, and in relation to the motivations that led the company to prepare a sustainability report for the first time, company $\mathrm{D}$ indicates that the report is in line with its desire "for transparency and for informing all our interested parties about performance in social and environmental matters".
The other companies agree with company $\mathrm{D}$ on the motivations for elaborating a sustainability report, with transparency of activities and satisfying the expectations of shareholders being the main reasons that the companies highlight.

The theory of legitimacy works in this context, since companies seek to reduce the existing gap between the desires of their relevant public and the perception of reality with the formulation of different strategies. To explain and justify their actions, the disclosure of sustainability information must be complete and transparent.

Table 2 shows in more detail the reasons that influence the publication of information on sustainability and the frequency of answer options. It is noted that three of the companies surveyed are "totally in agreement" and one "agrees" that transparency of activities is one of the main reasons for the publication of information on sustainability, which confirms the need to transform traditional positions (Husillos, 2007). Along this same line of argumentation, three of the companies studied are also "in agreement" that meeting the expectations of shareholders is one of the main reasons for the disclosure of such information. However, company B adds an additional reason to justify the disclosure:

"Sustainability reports are important tools for the diagnosis of internal management and are also an indicator of needs to improve or adjust the way in which the companys activities are conducted. Also, the expectations of stockholders must be considered 
an important and diversified usersoriginated source for the elaboration and dissemination of reports."
In turn, company $\mathrm{D}$ emphasizes that its main motivation is "to satisfy all our interested parties".

Table 2

\section{Reasons for the publication of sustainability information}

\begin{tabular}{|c|c|c|c|c|c|}
\hline \multirow[t]{2}{*}{ Reasons } & \multicolumn{5}{|c|}{ Assessment } \\
\hline & 1 & 2 & 3 & 4 & 5 \\
\hline In order to comply with legal regulations & A & $\mathrm{C}$ & & $\mathrm{BD}$ & \\
\hline Transparency of activities & & & & $\mathrm{D}$ & $\mathrm{ABC}$ \\
\hline By requirement of the shareholders & & & $\mathrm{AD}$ & B & $\mathrm{C}$ \\
\hline To obtain quality certification & & $\mathrm{BCD}$ & A & & \\
\hline To comply with the environmental management system & & $\mathrm{C}$ & $\mathrm{BD}$ & A & \\
\hline To participate in sustainable investment funds & A & $\mathrm{C}$ & $\mathrm{D}$ & B & \\
\hline To build a good image & & $\mathrm{D}$ & B & $\mathrm{C}$ & A \\
\hline To meet the expectations of shareholders & & & & $\mathrm{ABD}$ & $\mathrm{C}$ \\
\hline Other (please specify): & & & & $\mathrm{D}$ & B \\
\hline Total & 2 & 7 & 7 & 11 & 7 \\
\hline
\end{tabular}

Note: Scoring for the answers: 1- Totally disagrees; 2 - Disagrees; 3 - Indifferent; 4-Agrees; 5- Totally agrees.

All the companies highlight that the "workers" have a "high" interest in the publication of information on the sustainability of the company where they provide their services. Likewise, the "directors" represent an interest group mentioned by three of the companies interviewed with a "very high" interest in the publication of sustainability information. Consequently, internal stakeholders are also relevant and the legitimization of the company is aimed towards them.

Table 3

\section{Group of interest in the publication of sustainability information}

\begin{tabular}{|c|c|c|c|c|c|}
\hline \multirow[t]{2}{*}{ Stakeholders } & \multicolumn{5}{|c|}{ Assessment } \\
\hline & 1 & 2 & 3 & 4 & 5 \\
\hline Directors & & & $\mathrm{D}$ & & $\mathrm{ABC}$ \\
\hline Shareholders & & & & $\mathrm{BD}$ & $\mathrm{AC}$ \\
\hline Potential Investors & & & A & $\mathrm{BD}$ & $\mathrm{C}$ \\
\hline Consumers & & & $\mathrm{B}$ & ACD & \\
\hline Public Administrators & & $\mathrm{C}$ & $\mathrm{D}$ & B & A \\
\hline Non-Governmental Organizations & & & $\mathrm{D}$ & $\mathrm{AB}$ & $\mathrm{C}$ \\
\hline Workers & & & & $\mathrm{ABCD}$ & \\
\hline General Public & & & $\mathrm{ABD}$ & C & \\
\hline Other (please specify): & & & & $\mathrm{B}$ & \\
\hline Total & - & 1 & 8 & 16 & 8 \\
\hline
\end{tabular}

Note: Scoring for the answers: 1- Very low; 2-Low; 3 - Indifferent; 4- High; 5- Very high. 
It can be observed in the previous table that the companies analyzed have a wide range of interest groups. Thus, it seems that such organizations use a new style of management in which the principle of shared value is taken in consideration, choosing those actions that benefit both the company and its different interest groups (Moneva \& Ortas, 2009).

Consequently, it can be inferred that the needs and expectations of stakeholders must be considered in the decision-making processes of companies (Moneva, 2005a).

Cho and Patten (2007) suggest that the disclosure and extent of environmental information is a function of the degree of exposure of the organization to environmental pressures. The companies analyzed state that most of the proposed interest groups require and demand published sustainability information. When a company has a high commitment to the stakeholders, the company balances the legitimate interests of those groups in a justifiable way according to moral principles (Greenwood, 2007).

However, as indicated by the Spanish Association of Accounting and Administration (AECA, 2012), the development of non-financial environmental information is more recent and less structured than financial information, because it is information whose elaboration and publication is currently voluntary for companies and institutions. Although the importance of non-financial information is acknowledged by managers, shareholders, media, and other users, several factors contribute to its lower impact, among which are the lack of standardization in the presentation of information and the absence of a consortium or international regulatory institution with similar characteristics to the existing bodies in the financial area.

In general, this information is found in the sustainability report and, in this regard, Moneva (2005a) notes that sustainability reports have appeared to increase the transparency of organizations, although their main limitation is the necessary creation of measurable, comparable, and reliable information instruments. The author adds that the elaboration and dissemination of sustainability reports are a key element in improving the community's perceptions of the company.

Regarding the obligation of environmental non-financial information, it is observed in this study that three of the companies are "in agreement" that some type of environmental non-financial information should be mandatory. Companies C and D agree that sustainability indicators are a type of environmental nonfinancial information that should be mandatory. Company C emphasizes that the obligation should be aimed at "the transparency of the company's environmental and economic indicators"; while company D opts for "the indicators of the IPIECA and GRI reporting guidelines of the Oil \& Gas sector”. Company B emphasizes that “(...) if there is a need for transparency and publication of information on some specific aspects, it should be included in the laws, regulations, and other guidance documents".

Thus, it seems that the mandatory nature of CSR information will allow companies with a high impact to create a new, more homogeneous context, where legitimacy is achieved through compliance with legislation.

\subsection{Indexes and initiatives related to sustainability}

Socially responsible investors can also take as a reference, at the time of selecting their investments, sustainable stock exchange indexes (AECA, 2004). Consequently, participation in these indexes can influence the image of the company and help it to attract more resources or improve its performance in the market (Moneva, 2005b).

In relation to the participation of companies in a sustainable investment index or stock market index, two of those analyzed participate in the Dow Jones Sustainability Indexes and one of these two are also part of the FTSE 4Good IBEX.

Company B adds that "when the sustainability indexes are related to the stock market, the expectations of the "investor" public have a greater impact on the decision to form part 
of one of these indexes or not". Participation in these indexes could help the company to improve its reputation and be a way to achieve legitimacy in the eyes of its stakeholders.

Table 4 shows the reasons expressed by the interviewees regarding this participation. The option "to meet the expectations of all the interest groups" is the reason highlighted by 3 of the companies analyzed in the "agreement" category. The answers obtained allow us to deduce that the companies in the study recognize a significant number of interested parties in their management. According to Álvarez (2009), the company is a link between the interests of different participants or stakeholders, so the shareholders-managers relationship is not the only important one. The different explicit and implicit contracts are also relevant, the objective being the creation of net wealth for all agents, and not exclusively the generation of financial wealth, and not only for shareholders.

Table 4

\section{Reasons for participation in sustainable investment indexes}

\begin{tabular}{|c|c|c|c|c|c|}
\hline \multirow[t]{2}{*}{ Reasons } & \multicolumn{5}{|c|}{ Assessment } \\
\hline & 1 & 2 & 3 & 4 & 5 \\
\hline To portray a good image & & $\mathrm{D}$ & $\mathrm{B}$ & $\mathrm{C}$ & \\
\hline To attract new shareholders & & & $\mathrm{C}$ & $\mathrm{D}$ & B \\
\hline By requirement of the shareholders & & $\mathrm{D}$ & $\mathrm{B}$ & $\mathrm{C}$ & \\
\hline To meet the expectations of all stakeholders & & & & $\mathrm{BCD}$ & \\
\hline To meet the expectations of a specific interest group & & & & $\mathrm{D}$ & $\mathrm{B}$ \\
\hline \multicolumn{6}{|l|}{ Other (please specify): } \\
\hline Total & - & 2 & 3 & 7 & 2 \\
\hline
\end{tabular}

Note: Scoring for the answers: 1- Completely disagrees; 2-Disagrees; 3-Indifferent; 4-Agrees; 5-Totally agrees.

The companies analyzed participate in national and international associations and initiatives. The answers indicate that companies B, C, and D are part of the United Nations Global Compact and the Global Reporting Initiative (GRI); while company A participates exclusively in the GRI. One of the companies is also part of the Regional Association of Oil and Natural Gas Companies of Latin America and the Caribbean and of the International Petroleum Industry Environmental Conservation Association.

The adoption of the Global Compact initiatives as a performance mechanism for CSR results in companies behaving more responsibly and obtaining better performance as well as an improvement of their image and reputation (Cetindamar \& Husey, 2007).

As for the reasons that have led companies to participate in associations and national and international initiatives of this kind, company
A comments that its participation is due to its "own initiative and for having a standard of comparison". Company B highlights that "the Global Compact is one of the main drivers of the management of the company, in terms of social and environmental responsibility (...). GRI is a leading global reference in the elaboration of sustainability reports." In turn, company D details as the main reason for its participation "the fact of being able to share and work together".

In relation to the International Integrated Reporting Committee (IIRC) initiative, company B comments that "it follows the IIRC debates to integrate them in its reports in the coming years". In summary, the participation of the companies analyzed in various initiatives and associations has been verified, which is considered to be relevant.

The integrated information detailed in the IIRC initiative expresses the connections between strategy, government, and financial behavior and 
the economic, social, and environmental context in which the company operates. By reinforcing these connections, integrated information can help organizations to take more sustainable decisions and allow investors and other interest groups to know the true behavior and results of these (AECA, 2012).

Without doubt, participating in these associations and initiatives helps companies to have parameters to disseminate their environmental information, encourages the exchange of experiences, and facilitates the comparison of their indicators with those of other companies in the sector. In this sense, they agree with Parker (2005) when he indicates that there is a legal and moral obligation to report on the actions for which a firm is responsible to fully comply with the rendering of accounts.

\subsection{Elaboration and publication of sustainability reports}

With regard to the number of workers assigned exclusively to the sustainability department or similar of each of the companies surveyed, it was found that the highest number was 80 people and the lowest number was a single employee. In one of the companies there is no exclusive department to deal with issues such as safety, environment, energy efficiency, and health.

There are many departments that are involved in the elaboration of sustainability reports. In this regard, company A highlights that "our report is prepared under the coordination of the human resources area, with the participation of the safety, environment, and commercial production council"; while company B mentions that, in its elaboration, "the boards of directors of the parent company and the main subsidiaries participate." Company C details that "the general direction of sustainability and the technical directors of each business" are the units that participate in the elaboration of the sustainability report, and, in company D, they are "all the corporate areas and business/countries units". As can be seen, there is no agreement regarding the body responsible for the elaboration of the sustainability report. There is agreement on several bodies participating in its elaboration, and that is why it is an increasingly cross-sector issue.

Also, regarding the elaboration of the reports, the decision process concerning whether pieces of information should be disclosed or not, and what executives, departments, or units of the company are involved in that decision, the following results were found. Company A says, in summary, that this involves "the participation of the board of directors of the company". In turn, company C details that "the boards of directors of all the companies in the group are involved. The coordination is carried out by the group's General Sustainability Management, and the technical areas of all the companies in the group are responsible for determining the indicators".

Regarding the information to be included, there is also no unanimity of criteria among the companies, and they emphasize that the elaboration must consider the expectations of the interested parties. Companies B and D highlight the importance of following the guidelines of the GRI:

"The limits of the report are based on
the guidelines of the Global Reporting
Initiative. Several aspects are considered,
including the relevance, detailed in a
materiality test carried out by senior
executives and representatives of various
interest groups of the company."
(Company B)

"First, we follow the GRI reporting guide with application level $\mathrm{A}$, that is, we report at the highest level, and annually we identify the relevant expectations of our stakeholders and respond in the report on the performance of the identified concerns." (Company D)

Thus, it can be considered that companies do not consult their interest groups but respond to the issues because of the social sensitivity they generate.

In relation to the verification of the sustainability report, all the companies believe that the report must have external verification. Company $\mathrm{C}$ indicates that this is important for the "validation and auditing of published 
information." Company B highlights the following need:

\begin{abstract}
"To increase the reliability of the information, providing the team that writes the publication with validation that there was no loss of data in the flow of information, avoiding deviations that may go unnoticed due to the "bias" of anyone who is within the process and, therefore, does not contemplate the facts from the perspective of an outsider."
\end{abstract}

Finally, this study observed that three of the companies interviewed perform an external verification of the sustainability report. Moneva (2006) emphasizes that the growing relevance of sustainability information has accelerated the need to provide greater credibility through external verification, in the same way that auditing contributes credibility to the annual accounts. The objective of external verification is to provide the highest possible level of reliability to the data provided in the report. Total reliability cannot be accomplished, given the subjective nature of many of the aspects addressed (AECA, 2004).

Throughout the study, an almost homogeneous behavior was observed in the responses of the companies analyzed, however, companies B and D stand out for their more complete, detailed, and punctual responses. These companies are also the ones that participate the most in international initiatives. However, these differences do not influence the overall behavior of legitimizing through information.

\section{Conclusions}

The main aim of the study was to identify the reasons that may influence the elaboration and publication of the sustainability reports of four companies, using a multiple case study.

The companies in the study publish their sustainability report and essentially consider it to be an instrument of accountability to their stakeholders, although the decision of the company about the information to be disseminated depends on the legitimacy that it intends to achieve. Additionally, one of the main reasons that influence the publication is transparency in their activities.

The study shows these companies recognize that they have a broad range of interest groups and that these demand sustainability information. For the responsible behavior of companies, not only must a strategic orientation be presented, but a CSR commitment must also be made with all the stakeholders.

The companies analyzed participate in national and international associations and initiatives. These participations provide an exchange of experiences and can also be a form of legitimization since, according to O'Donovan (2002), companies must act within the limits of what society identifies as socially acceptable behavior.

The elaboration of sustainability reports is a complex task that requires the participation of several areas of a company. This difficulty is also manifested in the fact that there is no agreement on which body should be responsible for elaborating the report, as well as on the criteria for choosing the information that should be included. Considering that employees are also interested parties, the inclusion of a variety of them in the elaboration of sustainability reports could produce more complete reports.

The participation of external stakeholders in the process of elaborating a sustainability report and its external verification are also considered to be relevant and essential. However, the companies in the sample have not yet adopted a complete process of materiality based on the stakeholders. Moneva (2005a) highlights the need for stakeholders in organizations to take an active role and notes that they should not be mere readers of information, since their participation in the configuration of sustainability information is essential.

In short, the paper responds to the initial question by noting that companies in sensitive sectors seek organizational legitimization through sustainability information. However, this is 
accompanied by a process of internalization of the social and environmental implications of the activity.

It is important to note that conducting interviews with different stakeholders to identify their needs and expectations is a relevant aspect to be considered in future investigations to check whether such an internalization process exists.

The study carried out is qualitative and aimed at leading companies in their sectors and countries. Currently, most studies on sustainability information are quantitative and are carried out with North American and British companies, while this study focuses on Brazil and Spain.

For this paper, a form of study was developed that addresses the following aspects: sustainability information, the reasons for publication and interest groups, the indexes and initiatives related to sustainability, and the elaboration and publication of sustainability reports. Given the scarcity of studies in this area, this paper addresses several aspects of sustainability and can contribute to other studies, even in companies in different areas of activity from those surveyed here.

This study was carried in a small group of companies. It would have been enriched if a larger number of companies were analyzed and a greater number of interviews were conducted. However, considering the relevance of the companies interviewed and the difficulty of carrying out this type of study, we believe the paper offers some significant contributions.

In future research, it is important to develop studies that include interviews with different stakeholders (investors, shareholders, NGOs) and then compare the results.

\section{References}

Alazzani, A., \& Wan-Hussin, W. N. (2013). Global Reporting Initiative's environmental reporting: $A$ study of oil and gas companies. Ecological Indicators, 32, 19-34.

Albelda, E., Correa, C., \& Carrasco, F. (2007). Environmental management systems as an embedding mechanism: A research note.
Accounting, Auditing and Accountability Journal, 20(3), 403-422.

Álvarez, I. (2009). Las memorias de sostenibilidad: Un instrumento para la gestión de la sostenibilidad. Revista Española de Financiación y Contabilidad, 38(144), 677-697.

Archel, P. (2003). La divulgación de la información social y medioambiental de la gran empresa española en el período 1994-1998: Situación actual y perspectivas. Revista Española de Financiación y Contabilidad, 32(117), 571-601.

Asociación Española de Contabilidad y Administración de Empresas (2004). Marco conceptual de la responsabilidad social corporativa. Madrid: Autor.

Asociación Española de Contabilidad y Administración de Empresas (2012). Información integrada: El cuadro integrado de indicadores (CIIFESG) y su taxonomia XBRL. Madrid: Autor.

Baraibar-Diez, E., \& Satorrío, L. (2018). O efeito mediador da transparência na relação entre responsabilidade social corporativa e reputação corporativa. Revista Brasileira de Gestão de Negócios, 20(1), 5-21.

Bonsón, E., \& Bednárová, M. (2015). CSR reporting practices of Eurozone companies. Revista de Contabilidad, 18(2), 182-193.

Cetindamar, D., \& Husoy, K. (2007). Corporate social responsibility practices and environmentally responsible behavior: The case of the United Nations Global compact. Journal of Business Ethics, 76(2), 163-176.

Cho, C; Patten, D. (2007): The role of environmental disclosures as tools of legitimacy: A research note, Accounting, Organizations and Society, 32, pp. 639- 647.

Deegan, C., \& Blomquist, C. (2006). Stakeholder influence on corporate reporting: An exploration of the interaction between WWF-Australia and the Australian minerals industry, Accounting, Organizations and Society, 31(4-5), 343-372.

Deegan, C., Rankin, M., \& Tobin, J. (2002). An examination of the corporate social and 
environmental disclosures of BHP from 19831997: A test of legitimacy theory, Accounting, Auditing and Accountability Journal, 15(3), 312343.

Frost, G., \& Seamer, M. (2002). Adoption of environmental reporting and management practices: an analysis of new south wales public sector Entities. Financial Accountability and Management, 18(2), 103-127.

Gray, R., Owen, D., \& Adams, C. (1996). Accounting \& accountability. Changes and challenges in corporate social and environmental reporting. Hemel Hempstead: Prentice-Hall.

Greenwood, M. (2007). Stakeholder engagement: Beyond the myth of corporate responsibility. Journal of Business Ethics, 74(4), 315-327.

Hernández, F. (2012). Factores de desempeño y de información de responsabilidad social corporativa en la PYME (Tesis Doctoral). Universidad de Zaragoza, Zaragoza, España.

Husillos, F. (2007). Una aproximación desde la teoría de la legitimidad a la información medioambiental revelada por las empresas españolas cotizadas. Revista Española de Financiación y Contabilidad, 36(133), 97-121.

Husillos, J., Larrinaga, C., \& Álvarez, M. J. (2011). The emergence of triple bottom line reporting in Spain, Revista Española de Financiación y Contabilidad, 40(150), 195-219.

Iatridis, G. (2013). Environmental disclosure quality: Evidence on environmental performance, corporate governance and value relevance. Emerging Markets Review, 14, 55-75.

KPMG (2015). Currents of change. The KPMG survey of corporate responsibility reporting 2015. Rotterdam: Autor.

Larrinaga, C., Carrasco, F., Correa, C., Llena, F., \& Moneva, J.M. (2002). Accountability and accounting regulation: The case of the Spanish environmental disclosure standard. The European Accounting Review, 11(4), 7-29.

Llena, F. (1999). La contabilidad en la interacción empresa-medio ambiente. Su contribución a la gestión medioambiental (Tesis Doctoral). Universidad de Zaragoza, Zaragoza, España

Moneva, J. M. (2005a). Información corporativa y desarrollo sostenible. Economistas, 106, 70-79.

Moneva, J. M. (2005b). Información sobre responsabilidad social corporativa: Situación y tendencias. Revista Asturiana de Economía, (34), 43-67.

Moneva, J. M. (2006). Mecanismos de verificación de la información sobre responsabilidad social corporativa. Papeles de Economía Española, (108), 75-89.

Moneva, J. M., \& Ortas, E. (2009). Desarrollo sostenible e información corporativa. Revista Economia Industrial, (371), 139-154.

Moseñe, J., Burritt, R., Sanagustín, M., Moneva, J. M. \& Tingey-Holyoak, J. (2013). Environmental reporting in the Spanish wind energy sector: An institutional view. Journal of Cleaner Production, 40, 199-211.

Navarro, A., Alcaraz, J. M., \& Ortiz, D. (2010). La divulgación de información sobre responsabilidad corporativa en administraciones públicas: Un estudio empírico en gobiernos locales. Revista de Contabilidad, 13(2), 285-314.

O'Donovan, G. (2002). Environmental disclosures in the annual report. Extending the applicability and predictive power of legitimacy theory. Accounting, Auditing and Accountability Journal, 15(3), 344-371.

O’Dwyer, B. (2002). Managerial perceptions of corporate social disclosure: an Irish story. Accounting Auditing and Accountability Journal, 15(3), 406-436.

Parker, L. (2005). Social and environmental accountability research: A view from the commentary box. Accounting, Auditing and Accountability Journal, 18(6), 842-860.

Yin, R. (2009). Case Study Research. Design and Methods. London: Sage Publications. 


\section{APPENDIX}

\section{PART 1: ENVIRONMENTAL SUSTAINABILITY}

1. Do you believe there is a reason the company first decided to prepare a sustainability report?

2. In your opinion and using the scale proposed, indicate the reasons that influence the publication of sustainability information. ( 1 - totally disagree, 2 - disagree, 3 - indifferent, 4 - agree, 5 - totally agree)

\begin{tabular}{|c|c|c|c|c|c|}
\hline \multirow[t]{2}{*}{ Reasons } & \multicolumn{5}{|c|}{ Evaluation } \\
\hline & 1 & 2 & 3 & 4 & 5 \\
\hline \multicolumn{6}{|l|}{ To meet the legal requirements } \\
\hline \multicolumn{6}{|l|}{ Transparency of activities } \\
\hline \multicolumn{6}{|l|}{ By requirement of the shareholders } \\
\hline \multicolumn{6}{|c|}{ To obtain a quality certification } \\
\hline \multicolumn{6}{|c|}{ To comply with the environmental management system } \\
\hline \multicolumn{6}{|c|}{ To participate in sustainable investment funds } \\
\hline \multicolumn{6}{|c|}{ To portray a good image } \\
\hline \multicolumn{6}{|l|}{ To meet shareholder expectations } \\
\hline Others (indicate): & & & & & \\
\hline
\end{tabular}

3. In your opinion and using the scale proposed, which interest group may be interested in the publication of your company's sustainability information? (1 - very low, 2 - low, 3 - indifferent, 4 - high, 5 - very high)

\begin{tabular}{|c|c|c|c|c|c|}
\hline \multirow[t]{2}{*}{ Interest group } & \multicolumn{5}{|c|}{ Evaluation } \\
\hline & 1 & 2 & 3 & 4 & 5 \\
\hline \multicolumn{6}{|l|}{ Directors } \\
\hline \multicolumn{6}{|l|}{ Shareholders } \\
\hline \multicolumn{6}{|l|}{ Potential investors } \\
\hline \multicolumn{6}{|c|}{ Consumers } \\
\hline \multicolumn{6}{|c|}{ Public adminstrators } \\
\hline \multicolumn{6}{|c|}{ Non-governmental organizations } \\
\hline \multicolumn{6}{|c|}{ Workers } \\
\hline \multicolumn{6}{|l|}{ General public } \\
\hline Others (indicate): & & & & & \\
\hline
\end{tabular}

4. In your opinion, non-financial environmental information should generally be:
( ) Obligatory.
( ) Voluntary.
Why? 
5. Do you believe that any type of non-financial environmental information should be obligatory?

\begin{tabular}{|l|l|}
\hline ( ) & No \\
\hline ( ) Yes. Indicate:
\end{tabular}

6. Does the company participate in any sustainable investment stock exchange index? If your answer is yes, state the starting date of its participation and if it has left the index at any time.

\begin{tabular}{|l|l|}
\hline$(\quad)$ & Dow Jones Sustainability Indexes \\
\hline$(~)$ & FTSE 4Good IBEX \\
\hline$(\quad)$ & Global 100 \\
\hline$(\quad)$ & ISE \\
\hline$(\quad)$ & Does not participate \\
\hline$(\quad)$ & Other (indicate): \\
\hline
\end{tabular}

7. Starting date

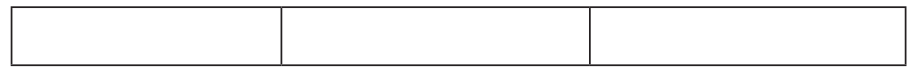

8. If it has left that index at any time, why?

9. If the company participates in any of the sustainable investment stock exchange indexes, evaluate using the proposed scale the reasons for its participation: ( 1 - totally disagree, 2 - disagree, 3 indifferent, 4 - agree, 5 - totally agree)

\begin{tabular}{|c|c|c|c|c|c|}
\hline \multirow[t]{2}{*}{ Reasons } & \multicolumn{5}{|c|}{ Evaluation } \\
\hline & 1 & 2 & 3 & 4 & 5 \\
\hline \multicolumn{6}{|c|}{ To portray a good image } \\
\hline \multicolumn{6}{|c|}{ To capture new investors } \\
\hline \multicolumn{6}{|c|}{ By requirement of the shareholders } \\
\hline \multicolumn{6}{|c|}{ To meet the expectations of all interest groups } \\
\hline \multicolumn{6}{|c|}{ To meet the expectations of a specific interest group. Indicate: } \\
\hline Other (indicate): & & & & & \\
\hline
\end{tabular}

10. Indicate the national and international associations and initiatives in which the company currently participates. Mark all those you consider necessary.

\begin{tabular}{|l|l|}
\hline$(\quad)$ & UN Global Compact \\
\hline$(\quad)$ & Global Reporting Initiative \\
\hline$(\quad)$ & Others (indicate): \\
\hline
\end{tabular}


11. Why does the company participate in the national and international associations and initiatives detailed in the previous question?

12. Do you know of any guiding initiatives for the elaboration of sustainability reports? Do you know of the IICR (International Integrated Reporting Committee) initiative?. If so, do you intend to adopt them?

13. Is there a department or part of one called sustainability or corporate social responsibility? If so, how many people are exclusively assigned to it?

\begin{tabular}{|l|l|}
\hline$(\quad)$ & No \\
\hline ( ) Yes. Indicate: \\
\hline
\end{tabular}

14. Which departments participate in the elaboration of the sustainability report?

15. Regarding the elaboration of sustainability reports, how does the company decide if an item of data should be disclosed or not and which company executives, departments, or units are involved in this decision?

16. In your opinion, is it important for the sustainability report to be externally verified?

\begin{tabular}{|l|l|} 
( ) Yes & ( ) No \\
\hline Why? & \\
\hline
\end{tabular}

17. Does the company carry out any external verification of the report?

\begin{tabular}{|l|l|}
\hline$($ ) & Yes \\
\hline ( ) No \\
\hline
\end{tabular}




\section{PART 2: PROFILE OF THE PERSON ANSWERING THE INTERVIEW}

18. How long has the person answering the interview been at the company?

\begin{tabular}{|l|l|}
\hline$(\quad)$ & Less than 3 years \\
\hline$(\quad)$ & Between 3 and 5 years \\
\hline$(\quad)$ & Between 6 and 8 years \\
\hline$(\quad)$ & More than 8 years \\
\hline
\end{tabular}

19. Person's name, telephone number, position, and department

\section{Notes:}

1 A preliminary version of this paper is part of the doctoral thesis «FACTORS OF DISCLOSURE OF ENVIRONMENTAL INFORMATION IN THE WORLD OIL SECTOR» presented by Darliane Ribeiro Cunha and guided by José Mariano Moneva, 2016.

\section{Supporting Agencies:}

CAPES (Coordenação de Aperfeiçoamento de Pessoal de Nível Superior)

Ministry of Economy, Industry, and Competitiveness (Spain), Research Project "ECO-CIRCULAR" -

Ref. ECO2016-74920-C2-1-R.

\section{About the Authors:}

1. Darliane Ribeiro Cunha, PhD in Accounting and Finance, Universidad de Zaragoza

E-mail: darliane@me.com.

ORCID

(D)0000-0003-2548-1237

2. José Mariano Moneva, $\mathrm{PhD}$ in Accounting and Finance, Universidad de Zaragoza.

E-mail: jmmoneva@unizar.es.

ORCID

(D)0000-0003-1619-8042

\section{Contribution of each author:}

\begin{tabular}{lcc}
\hline Contribution & Darliane Ribeiro Cunha & José Mariano Moneva \\
\hline 1. Definition of research problem & $\sqrt{ }$ & $\sqrt{ }$ \\
2. Development of hypotheses or research questions (empirical studies) & $\sqrt{ }$ & $\sqrt{ }$ \\
3. Development of theoretical propositions (theoretical work) & $\sqrt{ }$ & $\sqrt{ }$ \\
4. Theoretical foundation/ Literature review & $\sqrt{ }$ \\
5. Definition of methodological procedures & $\sqrt{ }$ \\
6. Data collection & $\sqrt{ }$ \\
7. Statistical analysis & $\sqrt{ }$ \\
8. Analysis and interpretation of data & $\sqrt{ }$ \\
9. Critical revision of the manuscript & & $\sqrt{ }$ \\
10. Manuscript writing & $\sqrt{ }$ & $\sqrt{ }$ \\
\hline
\end{tabular}

